\title{
Performance of subsurface flow constructed wetland taking pretreated swine effluent under heavy loads
}

\author{
Chi-Yuan Lee ${ }^{\text {a,* }}$, Chun-Chih Lee ${ }^{b}$, Fang-Yin Lee ${ }^{b}$, Szu-Kung Tseng ${ }^{c}$, Chiu-Jung Liao ${ }^{b}$ \\ ${ }^{a}$ Water Resources and Environmental Engineering Program, Department of Harbor and River Engineering, \\ National Taiwan Ocean University, Keelung 20224, Taiwan, ROC \\ ${ }^{\mathrm{b}}$ Department of Environmental Engineering and Science, National Pingtung University of Science and Technology, \\ Nei Pu, Pingtung 91207, Taiwan, ROC \\ ${ }^{\mathrm{c}}$ Graduate Institute of Environmental Engineering, National Taiwan University, Taipei, Taiwan, ROC \\ Received 25 March 2003; received in revised form 12 August 2003; accepted 20 August 2003
}

\begin{abstract}
Subsurface flow constructed wetlands (SSFCW) subjected to changing of loading rates are poorly understood, especially when used to treat swine waste under heavy loads. This study employed a SSFCW system to take pretreated swine effluent at three hydraulic retention times (HRT): 8.5-day HRT (Phase I), 4.3-day HRT (Phase II), and 14.7-day HRT (Phase III). Results showed that the system responded well to the changing hydraulic loads in removing suspended solids (SS) and carbonaceous oxygen demands. The averaged reduction efficiencies for four major constituents in the three phases were: SS 96-99\%, chemical oxygen demand (COD) 77$84 \%$, total phosphorus $47-59 \%$, and total nitrogen (TN) $10-24 \%$. While physical mechanisms were dominant in removing pollutants, the contributions of microbial mechanisms increased with the duration of wetland use, achieving $48 \%$ of COD removed and $16 \%$ of TN removed in the last phase. Water hyacinth made only a minimal contribution to the removal of nutrients. This study suggested that the effluent from SSFCW was appropriate for further treatment in land applications for nutrient assimilation.
\end{abstract}

(C) 2003 Elsevier Ltd. All rights reserved.

Keywords: Constructed wetlands; Swine effluent; Suspended solids; Chemical oxygen demand; Total nitrogen; Total phosphorus; Removal mechanisms; Water hyacinth; Anaerobic conditions

\section{Introduction}

Swine wastewaters contain highly concentrated pollutants, including suspended solids, organics, and nutrients, and may deteriorate the quality of aquatic environments into which they are discharged (Stone et al., 1998). To lessen the impact, treatment of piggery wastewater before discharge has been proposed and further practiced by employing constructed wetlands, for these systems have significant merits of low capital and operating costs, and versatile removal mechanisms. (Hammer et al., 1993; Cronk, 1996; Kadlec and Knight, 1996; Hill and Sobesy, 1998; Humenik et al., 1999; Neralla et al., 2000; Szögi et al., 2000). Of constructed wetlands used for swine wastewater treatment, most are surface flow systems, only a few belong to subsurface

\footnotetext{
${ }^{*}$ Corresponding author. Fax: +886-2-24624770.

E-mail address: cylee@mail.ntou.edu.tw (C.-Y. Lee).
}

flow types (Hunt and Poach, 2001). With rising concerns of sustainable management of bioresource, and more stringent effluent standards, swine wastewater treatment by subsurface flow constructed wetlands (SSFCW) can be a great potential and challenge.

Traditionally, the SSFCW system was employed as terminal treatment component, where it was designed and operated at rather low loads for purpose of producing effluent that could meet discharged criteria. But it appeared that this treatment goal could not be achieved (Finlayson et al., 1987; Sievers, 1997). For example, Sievers (1997) used an anaerobic lagoon to pretreat swine wastewaters, giving low loadings of 17-20 $\mathrm{kg} \mathrm{ha}^{-1} \mathrm{~d}^{-1}$ BOD on wetland cells, but effluent concentrations from their wetlands had difficulty in meeting discharge limit of $30 \mathrm{mgl}^{-1}$ BOD. Thus, novel approaches to solve the problem are urgent, and one of them may be in allowing the SSFCW systems worked as a part in integrated sustainable management systems. That is, the SSWCW is operated to fully explore its 
capability in removing suspended solids and organics, followed by land applications as final disposal for nutrient assimilation (Szögi et al., 2000; Hunt and Poach, 2001). As such, polished treatment is not required for wetland, and neither is dilution of wastewater for soil treatment (Szögi et al., 2000). In this treatment alternative an important issue arises in what and how the SSFCW perform under heavy loads, to which available information is very limited.

Another issue in the performance of SSFCW system under heavy loads is the effects of fluctuations of loading rates. Though the dynamic loadings occurring frequently in constructed wetlands, most studies have focused on experiment with independent cells, where each cell was operated at a particular load in parallel (Dierberg et al., 2002). For improving the wetland treatment performance during a transition period, it becomes increasingly important to examine the response of the system to the changing flow rates and influent concentrations.

In this investigation, a mesocosm SSFCW, built in southern Taiwan, was tested for its capability in taking pretreated swine effluent under changes of heavy loads. Experiments were carried out in three consecutive phases, and each phase was controlled with a particular hydraulic retention time (HRT). The specific objectives of this study were: (i) to examine the wetland performance during operations at the three high loading rates; and (ii) to quantify the contributions made by physical, microbial, and plant uptake mechanisms in removing pollutants.

\section{Methods}

\subsection{Wetland operations}

The SSFCW system, located in a livestock farm in Pingtung County, Taiwan, is schematically illustrated in Fig. 1. Prior to discharge into the SSFCW reactor, raw swine wastewater from slatted floor units was pretreated with a existing three-stage facility, including solid separation, anaerobic digestion (with hydraulic retention time, HRT, of 20 days), and aerobic oxidation (HRT of $12 \mathrm{~h}$ ) followed by final clarification (HRT of $6 \mathrm{~h}$ ). The operation of SSFCW was controlled using HRT as main parameter. There are three phases conducted in this study over a period of 244 days. Each phase was operated at a specific HRT, namely, 8.5-day HRT (Phase I), 4.3-day HRT (Phase II), and 14.7-day HRT (Phase III). The averaged ambient temperatures were $25^{\circ} \mathrm{C}$ for Phase I, $22{ }^{\circ} \mathrm{C}$ for Phase II, and $24^{\circ} \mathrm{C}$ for Phase III.

\subsection{Constructed wetland}

As illustrated in Fig. 2, the wetland trench was $0.65 \mathrm{~m}$ deep, $9.5 \mathrm{~m}$ long $\times 2.6 \mathrm{~m}$ wide at the bottom and $10.3 \mathrm{~m}$ long $\times 4.2 \mathrm{~m}$ wide at the top. The empty-bed volume of

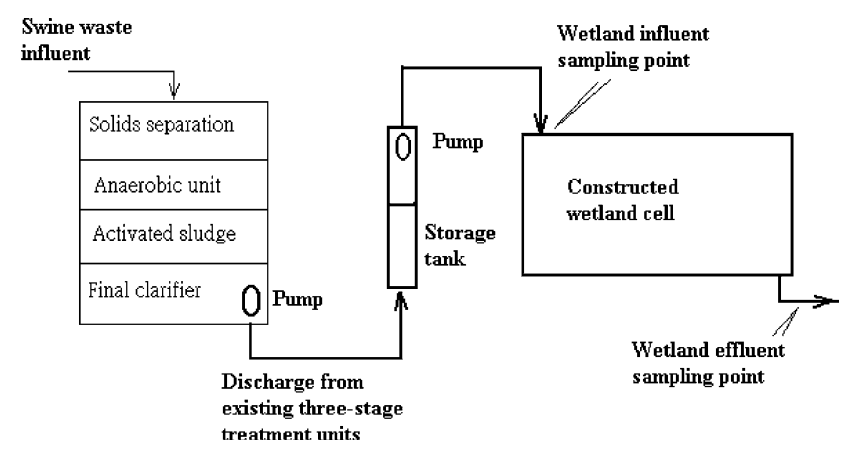

Fig. 1. Schematic diagram of newly built constructed wetland for treating swine effluent discharged from existing pretreatment units, including solid separator, anaerobic unit, activated sludge reactor, and final clarifier.
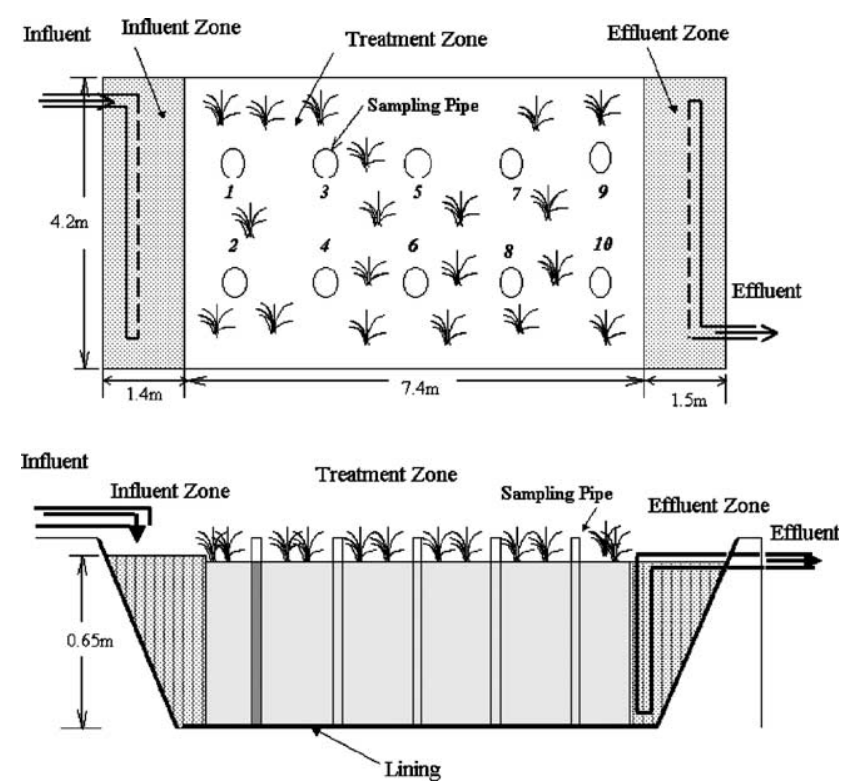

Fig. 2. Dimensions of constructed wetland of top view (top) and side view (bottom).

the wetland cell was approximately $22 \mathrm{~m}^{3}$. The trench bottom and walls were lined with $1.5-\mathrm{mm}$ high-density polyethylene to prevent leakage. Meanwhile, the whole wetland cell was divided into influent, treatment and effluent zones, each filled with different gravel media. In the treatment zone, the media mostly comprised gravel with a diameter of $1.27-1.91 \mathrm{~cm}$, while the remaining two zones were filled with gravel, mostly having diameter of 1.91-2.54 cm. Two submerged pumps transferred the influent wastewater from the existing final clarifier to the wetland site. Upon entering the influent zone surface, the wastewater flowed down through the treatment zone, and discharged from the effluent zone into a nearby brook. Initially, 30 stems of water hyacinth (Eichhornia crassipes) were planted in the treatment zone, which was taken from a nearby lagoon $\left(\approx 1600 \mathrm{~m}^{3}\right.$ in size). The influent to the lagoon was the 
same as to the wetland. Water hyacinth, instead of commonly used plant species of cattails or bulrush, was chosen in this study because the information about this plant in SSFCW systems is still lacking.

\subsection{Chemical analyses}

Wetland performance was monitored by periodic sampling at locations of influent and effluent lines during the course of study. The dissolved oxygen (DO), measured by YSI oxygen probe, and oxidation-reduction potential (ORP), measured by JENCO 6071, were determined in the field. Meanwhile, other measurements were performed from field samples that were immediately transferred to the laboratory. Suspended solids (SS), biochemical oxygen demand $\left(\mathrm{BOD}_{5}\right)$, ammonia nitrogen $(\mathrm{AN})$, nitrite nitrogen (nitrite $\mathrm{N}, \mathrm{NO}_{2}^{-}-\mathrm{N}$ ), nitrate nitrogen (nitrate $\mathrm{N}, \mathrm{NO}_{3}^{-}-\mathrm{N}$ ), total Kjeldahl nitrogen (TKN), total nitrogen (TN), orthophosphate (OP, $\left.\mathrm{PO}_{4}^{3-}-\mathrm{P}\right)$, and total phosphorus (TP), were analyzed according to standard methods (APHA, 1989). Finally, chemical oxygen demand (COD) was determined using a HACH DR/3000 spectrophotometer.

The water hyacinth was analyzed to determine its chemical composition including water, nitrogen, and phosphorus. Water content was determined gravimetrically by placing plant samples in the oven at $103{ }^{\circ} \mathrm{C}$ overnight with before and after weighing. Meanwhile, nitrogen content was ascertained with a procedure similar to that for determining TKN, as stated above. To measure phosphorus levels, plant samples were first digested, and then the digested samples were placed in a spectrophotometer (Hitachi spectrophotometer U-2000) to measure the light adsorbed at the $420 \mathrm{~nm}$ wavelength.

\subsection{Statistical analysis}

The mean and standard deviation of the measurements for each tested phase were calculated based on collected samples ( $n$ ), where $n=23$ in Phase I, $n=21$ in Phase II, and $n=16$ in Phase III. Differences in influent, effluent, and removal efficiency among the three phases were tested at a significance level of 0.05 with $F$ statistics (SPSS 10.0, SPSS, Inc., 1999).

\section{Results and discussion}

\subsection{Performance of subsurface flow constructed wetland}

The treated swine effluent to the wetland contained significant amounts of pollutants, though it had been pretreated to remove some suspended solids and other constituents (Fig. 3). With highly concentrated pollutants in the influent, the mass loading rates to the SSFCW (Table 1) was one order of magnitude higher
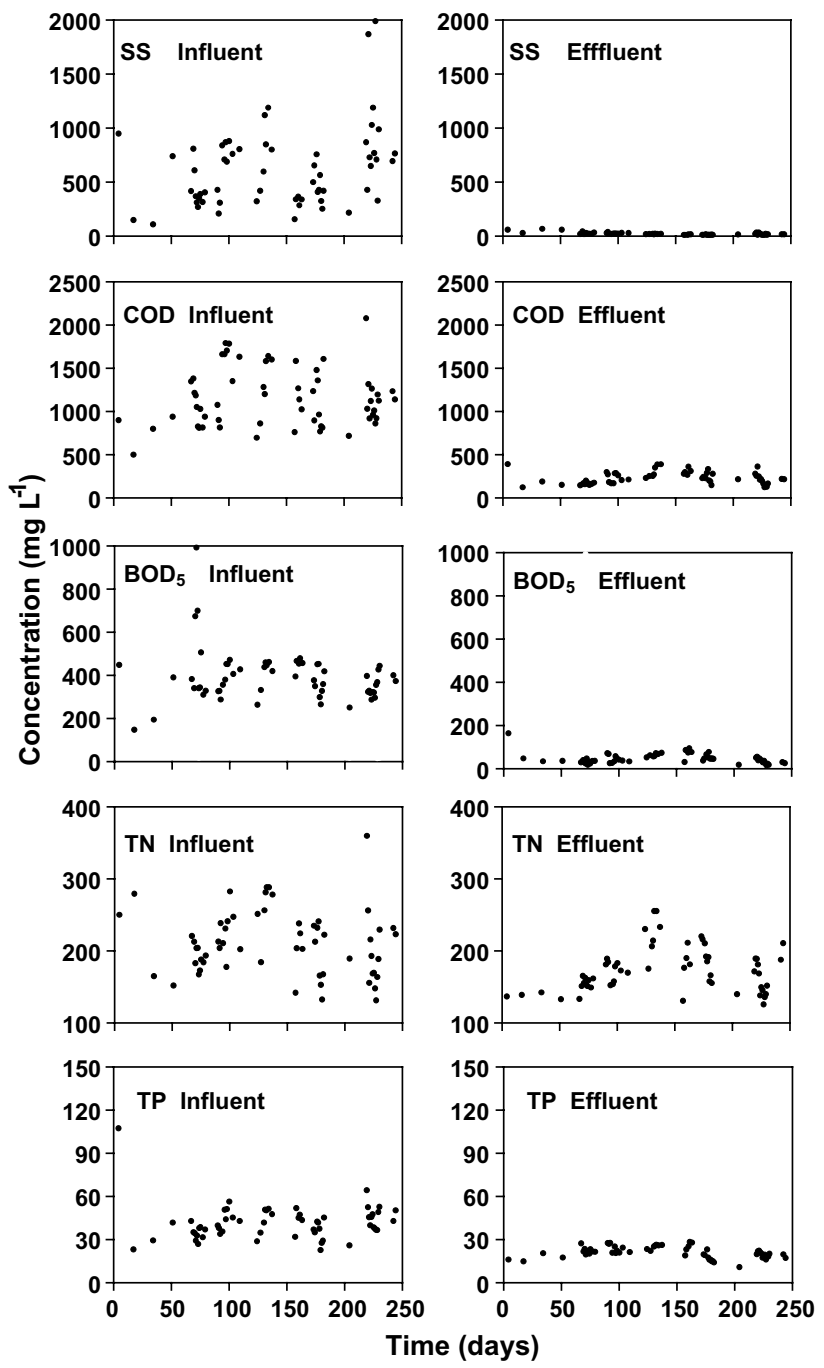

Fig. 3. Fluctuations of key pollutant concentrations in the influent and effluent of the constructed wetland during the operation period of 244 days. The abbreviations for pollutant are: SS, suspended solids; COD, chemical oxygen demand; $\mathrm{BOD}_{5}$, biochemical oxygen demand; $\mathrm{TN}$, total nitrogen; and TP, total phosphorus.

than applied to most wetlands (Knight et al., 2000). The averaged measurements in influent over three phases were: SS 519-873 $\mathrm{mgl}^{-1}$, COD 1115-1160 $\mathrm{mgl}^{-1}$, BOD 343-411 mg $1^{-1}$, TN 200-218 $\mathrm{mgl}^{-1}$, and TP 39-44 $\mathrm{mgl}^{-1}$ (Table 2).

Before the effects of loading rates on treatment performance were examined, differences in averaged concentrations of influent for major pollutants among the three phases were tested with $F$ statistics. As shown in Table 3, the influent concentrations of the COD, $\mathrm{BOD}_{5}$, $\mathrm{AN}$, TN, and TP, except SS, were not different significantly $(p>0.05)$. The large variations of averaged influent SS to this wetland could be negligible because the wetland was operated sufficiently below the normal SS loadings. Thus, the strength of the influent to the wetland could be considered as the same level over the three 
Table 1

Loading rates to the subsurface flow constructed wetlands

\begin{tabular}{llcccc}
\hline Item $^{\mathrm{a}}$ & Unit & Phase I & Phase II & Phase III & Other wetlands \\
\hline HRT & $\mathrm{d}$ & 8.5 & 4.3 & 14.7 & $(4.3-7.0)^{\mathrm{b}},(5-10)^{\mathrm{c}}$ \\
Hydraulic loading rate & $\mathrm{cm} \mathrm{d}^{-1}$ & 6 & 12 & 3.5 & $(1.5-2.4)^{\mathrm{b}},(0.6-1.9)^{\mathrm{c}}$ \\
SS & $\mathrm{kg} \mathrm{ha}^{-1} \mathrm{~d}^{-1}$ & 312 & 624 & 303 & $(66-90)^{\mathrm{b}},(27-39)^{\mathrm{c}}$ \\
COD & $\mathrm{kg} \mathrm{ha}^{-1} \mathrm{~d}^{-1}$ & 700 & 1370 & 390 & $(82-120)^{\mathrm{c}}$ \\
BOD & 247 & 474 & 119 & $(17-20)^{\mathrm{b}}$ \\
AN & $\mathrm{kg} \mathrm{ha}^{-1} \mathrm{~d}^{-1}$ & 110 & 220 & 60 & $(23-32)^{\mathrm{b}}$ \\
TN & $\mathrm{kg} \mathrm{ha}^{-1} \mathrm{~d}^{-1}$ & 125 & 262 & 69 & $\left(33-52\right.$ for KN K $^{\mathrm{c}}$ \\
TP & $\mathrm{kg} \mathrm{ha}^{-1} \mathrm{~d}^{-1}$ & 24 & 47 & 15 & $(15-24)^{\mathrm{b}},(2.5-3.7)^{\mathrm{c}}$ \\
\hline
\end{tabular}

${ }^{\mathrm{a}}$ The abbreviations are: HRT, hydraulic retention time; SS, suspended solids; COD, chemical oxygen demand; $\mathrm{BOD}_{5}$, biochemical oxygen demand; $\mathrm{KN}$, Kjeldahl nitrogen; $\mathrm{AN}$, ammonium nitrogen $\left(\mathrm{NH}_{4}^{+}-\mathrm{N}\right)$; $\mathrm{TN}$, total nitrogen; and $\mathrm{TP}$, total phosphorus.

${ }^{\mathrm{b}}$ Sievers (1997).

${ }^{\mathrm{c}}$ Finlayson et al. (1987).

Table 2

Averaged concentrations of influent and effluent for the constructed wetland over three phases of study

\begin{tabular}{|c|c|c|c|c|c|c|c|c|c|}
\hline \multirow[t]{2}{*}{ Item $^{\mathrm{a}}$} & \multicolumn{3}{|l|}{ Phase I } & \multicolumn{3}{|l|}{ Phase II } & \multicolumn{3}{|l|}{ Phase III } \\
\hline & Influent $^{\mathrm{b}, \mathrm{c}}$ & Effluent $^{\mathrm{b}, \mathrm{c}}$ & $\mathrm{RE}^{\mathrm{d}}$ & Influent ${ }^{\mathrm{b}, \mathrm{c}}$ & Effluent ${ }^{\mathrm{b}, \mathrm{c}}$ & $\mathrm{RE}^{\mathrm{d}}$ & Influent $^{\mathrm{b}, \mathrm{c}}$ & Effluent ${ }^{\mathrm{b}, \mathrm{c}}$ & $\mathrm{RE}^{\mathrm{c}}$ \\
\hline SS & $519(256)$ & $21(14)$ & 96 & $519(271)$ & $6(4)$ & 99 & $873(480)$ & $10(6)$ & 99 \\
\hline COD & $1160(367)$ & $190(62)$ & 84 & $1160(319)$ & $264(62)$ & 77 & $1115(300)$ & $198(61)$ & 82 \\
\hline $\mathrm{BOD}_{5}$ & $411(170)$ & $39(28)$ & 91 & $394(68)$ & $56(16)$ & 86 & $343(52)$ & $28(12)$ & 92 \\
\hline $\mathrm{NH}_{4}^{+}-\mathrm{N}$ & $185(27)$ & 144 (19) & 22 & $184(41)$ & $183(28)$ & 1 & $161(41)$ & $151(22)$ & 6 \\
\hline $\mathrm{NO}_{2}^{-}-\mathrm{N}$ & $0.06(0.02)$ & $0.03(0.01)$ & 50 & $0.07(0.10)$ & $0.04(0.02)$ & 43 & $0.04(0.01)$ & $0.03(0.01)$ & 25 \\
\hline $\mathrm{NO}_{3}^{-}-\mathrm{N}$ & $3.7(3.5)$ & $1.7(2.2)$ & 54 & $1.7(1.6)$ & $1.1(1.1)$ & 35 & $3.4(1.6)$ & $1.2(1.0)$ & 65 \\
\hline TKN & $204(34)$ & 156 (17) & 24 & $216(47)$ & $196(31)$ & 9 & $197(56)$ & $159(24)$ & 19 \\
\hline $\mathrm{TN}$ & 208 (34) & $158(16)$ & 24 & $218(47)$ & $197(32)$ & 10 & $200(54)$ & $160(25)$ & 20 \\
\hline $\mathrm{PO}_{4}^{3-}-\mathrm{P}$ & $28.1(4.5)$ & $19.2(4.3)$ & 32 & $28.9(5.1)$ & $19.8(4.3)$ & 31 & $28.7(6.7)$ & $17.6(2.8)$ & 39 \\
\hline $\mathrm{TP}$ & $40.3(15.8)$ & $21.2(3.3)$ & 47 & $39.4(8.5)$ & 20.9 (4.6) & 47 & $43.6(9.1)$ & $18.0(2.8)$ & 59 \\
\hline ORP & $-345(12)$ & $-310(17)$ & $\mathrm{e}^{\mathrm{e}}$ & $-349(11)$ & $-316(10)$ & - & $-323(22)$ & $-296(16)$ & - \\
\hline DO & $0.12(0.03)$ & $0.10(0.01)$ & - & $0.15(0.05)$ & $0.13(0.05)$ & - & $0.14(0.04)$ & $0.13(0.03)$ & - \\
\hline
\end{tabular}

${ }^{\mathrm{a}}$ The abbreviations are: SS, suspended solids; COD, chemical oxygen demand; $\mathrm{BOD}_{5}$, biochemical oxygen demand; TKN, total Kjeldahl nitrogen; $\mathrm{TN}$, total nitrogen; TP, total phosphorus; ORP, oxidation-reduction potential; and DO, dissolved oxygen.

${ }^{\mathrm{b}}$ Units for water quality indicators are $\mathrm{mg} \mathrm{l}^{-1}$ except ORP $(\mathrm{mV})$.

${ }^{\mathrm{c}}$ The number inside the parenthesis is standard deviation.

${ }^{\mathrm{d}} \mathrm{RE}$ represents removal efficiency (\%).

${ }^{\mathrm{e}}$ Not applicable.

Table 3

$F$-statistics tests for differences in influent and effluent concentrations, and removal efficiencies among three phases

\begin{tabular}{|c|c|c|c|}
\hline \multirow[t]{2}{*}{ Item $^{\mathrm{a}}$} & \multicolumn{3}{|l|}{$F$-test ${ }^{\mathrm{b}}$} \\
\hline & Influent & Effluent & $\begin{array}{l}\text { Removal } \\
\text { efficiency }(\%)\end{array}$ \\
\hline SS & $6.132^{* *}$ & $13.692^{* * *}$ & $4.048^{*}$ \\
\hline COD & 0.176 & $7.881^{* *}$ & $4.049^{*}$ \\
\hline $\mathrm{BOD}_{5}$ & 1.523 & $6.853^{* *}$ & $3.692^{*}$ \\
\hline $\mathrm{NH}_{4}^{+}-\mathrm{N}$ & 2.450 & $16.789^{* * *}$ & $12.503^{* * *}$ \\
\hline $\mathrm{TN}$ & 0.619 & $14.704^{* * *}$ & $6.490^{* *}$ \\
\hline $\mathrm{TP}$ & 0.532 & $3.815^{*}$ & $8.459^{* *}$ \\
\hline
\end{tabular}

${ }^{\mathrm{a}}$ The abbreviations are: SS, suspended solids; COD, chemical oxygen demand; $\mathrm{BOD}_{5}$, biochemical oxygen demand; $\mathrm{TN}$, total nitrogen; and TP, total phosphorus.

${ }^{\mathrm{b}}$ Difference in influent concentrations among three phases is tested using $F$ statistics. Significance is expressed as ${ }^{*} P<0.05 ;{ }^{* *} P<0.01$; and ${ }^{* * *} P<0.001$. Similar testes are also performed for effluent concentrations, and removal efficiency. phases. On the contrary, $F$-test showed that difference in the effluent concentrations for the above six measurements differed significantly $(p<0.05)$. In each phase treatment performance of the SSFCW is illustrated below.

\subsubsection{Phase I: 8.5-day HRT (day 1-day 109)}

The SSFCW system was started with a medium hydraulic loading of 8.5 days HRT, but under quite heavily loads as expressed in mass loading rates, 312 $\mathrm{kg} \mathrm{ha}^{-1} \mathrm{~d}^{-1}$ for SS, $700 \mathrm{~kg} \mathrm{ha}^{-1} \mathrm{~d}^{-1}$ for COD, and 247 $\mathrm{kg} \mathrm{ha}^{-1} \mathrm{~d}^{-1}$ for $\mathrm{BOD}_{5}$ (Table 1). Over a period of 109 days in operation, the wetland produced consistently good effluent, although the influent concentrations varied to a significant extent (Fig. 3). The averaged effluent SS was $21 \mathrm{mgl}^{-1}$, COD was $190 \mathrm{mgl}^{-1}$, and BOD $_{5}$ was $39 \mathrm{mg} \mathrm{l}^{-1}$, which gave removal efficiencies of $96 \%$ for SS, $84 \%$ for COD, and $91 \%$ for $\mathrm{BOD}_{5}$ (Table 2). These 
averaged effluent concentrations could achieve effluent, for example, concentration demand in Taiwan, of $\mathrm{SS}<150 \mathrm{mgl}^{-1}, \mathrm{COD}<250 \mathrm{mgl}^{-1}$, and $\mathrm{BOD}_{5}<80$ $\mathrm{mg} 1^{-1}$.

The removals of nutrients however, were not as good as those of $\mathrm{SS}, \mathrm{COD}$, and $\mathrm{BOD}_{5}$. The averaged influent TN concentration to the SSFCW was dominated by $\mathrm{AN}$, giving loading rates of $110 \mathrm{~kg} \mathrm{ha}^{-1} \mathrm{~d}^{-1}$ for $\mathrm{AN}$ and $125 \mathrm{~kg} \mathrm{ha}^{-1} \mathrm{~d}^{-1}$ for TN (Table 1). After treatment, the averaged effluent concentrations in AN were $144 \mathrm{mg}^{-1}$ and $158 \mathrm{mg}^{-1}$ in $\mathrm{TN}$, giving reduction efficiencies of $22 \%$ for AN and $24 \%$ for TN (Table 2). The SSFCW system removed about half of TP, giving averaged effluents in TP $21.2 \mathrm{mg} \mathrm{l}^{-1}$, and OP $19.2 \mathrm{mg} \mathrm{l}^{-1}$, even at a high TP loading rate of $24 \mathrm{~kg} \mathrm{ha}^{-1} \mathrm{~d}^{-1}$. Though the SSFCW system removed significant mass of nutrients, the nitrogen and phosphorus concentrations in the produced effluent were unacceptable for discharge. Here, for example, the effluent concentrations of nutrients were about one order of magnitude higher than the normal discharge permits, $10 \mathrm{mg}^{-1}$ for AN and $4 \mathrm{mg}^{-1}$ for OP. This large discrepancy implied that it would be very difficult to achieve effluent nutrient criteria by manipulating loading. Instead, it can be operated with heavy loads to fully explore its capability in removing organics, while reusing nutrients contained in the effluent.

\subsubsection{Phase II: 4.3-day HRT (day 110-day 182)}

The hydraulic loading to the SSFCW system was doubled in Phase II. The system responded well in removing SS, COD, and $\mathrm{BOD}_{5}$ (Table 1). The averaged effluent SS achieved was $6 \mathrm{mg}^{-1}$ (reduction efficiency of $99 \%$ ), even better than that in Phase I. Nevertheless, the increasing hydraulic load made the removals of COD and $\mathrm{BOD}_{5}$ slightly poorer, leading to the averaged effluent concentrations of COD increasing to $264 \mathrm{mg}^{-1}$ and $\mathrm{BOD}_{5}$ to $56 \mathrm{mg}^{-1}$, although the effluent $\mathrm{BOD}_{5}$ was still acceptable for discharge. The reduction efficiencies were down to $77 \%$ for $\mathrm{COD}$ and $86 \%$ for $\mathrm{BOD}_{5}$.

A very low efficiency appeared in the removals of nitrogen; the averaged effluent $\mathrm{AN}$ abruptly increased to $183 \mathrm{mg} \mathrm{l}^{-1}$ and TN to $197 \mathrm{mg} \mathrm{l}^{-1}$, making the removal efficiencies down to $1 \%$ for $\mathrm{AN}$ and $10 \%$ for TN. The removals of phosphorus were similar to those in Phase I, being little affected by the increasing loading rates.

\subsubsection{Phase III: 14.7-day HRT (day 183-day 244)}

In the last phase, the load to the SSFCW system was reduced to only half of that in Phase I to examine the degree to which the removal of pollutants could be improved. The removal efficiency of SS maintained the same high level of $99 \%$. The COD averaged effluent concentration was down to $198 \mathrm{mg}^{-1}$ and removal efficiency up to $82 \%$. The removal of $\mathrm{BOD}_{5}$, however, became the highest among the three phases, with an averaged effluent concentration down to $28 \mathrm{mg}^{-1}$, and removal efficiency increased to $92 \%$.

Though the nitrogen removal efficiencies had recovered from Phase II, they were still worse than in Phase I. The averaged effluent concentrations were $151 \mathrm{mgl}^{-1}$ (6\% reduction efficiency) in $\mathrm{AN}$, and $160 \mathrm{mgl}^{-1}(20 \%$ reduction efficiency) in TN. The TP was effectively removed in this phase, with the averaged TP effluent down to the $18 \mathrm{mg} \mathrm{l}^{-1}$, with removal efficiency the highest at $59 \%$.

\subsection{Removal mechanisms}

Pollutants in the SSFCW system undergo complex transport and transformation, involving biotic and abiotic processes. The contributions to removing pollutants by physical, microbiological, and plant uptake mechanisms are displayed in Table 4.

The suspended solids were removed entirely by physical processes, involving sedimentation, filtration, and adsorption. In this wetland, even at the applied load of 4.3-day HRT, the physical mechanism removed 618 $\mathrm{kg} \mathrm{ha}^{-1} \mathrm{~d}^{-1}$ of SS mass with efficiency of $99 \%$, indicating that the applied load had not yet reached its maximum allowable capacity. However, though the system is effective in removing SS, appropriate pretreatment to remove major portions of SS in the raw swine wastewater is still necessary, because it can prevent the wetland from being rapidly clogged.

The excellent COD removal was accomplished by good cooperation between physical and microbial mechanisms, where the former mechanism made $52-74 \%$ of contribution, and the latter $26-48 \%$ (Table 4). There are three important features possessed by this SSFCW system that make the wetland powerful in removing COD under heavy loads. First, owing to the physical separation mechanism, the organic solids could be settled out and retained in the wetland cell for a longer time, thus allowing better hydrolysis of organic solids for biodegradation to proceed easily. Second, gravel media placed inside the wetland cell allowed the accumulation of immense amounts of attached bacteria, which were very helpful in rapidly catalyzing chemical reactions. And third, organics biodegradation underwent anaerobic pathways. As such, the limitation of oxygen supply could be avoided, and moreover, maintaining anaerobic conditions inside the wetland cell provides advantage of low sludge production, which can largely prevent the wetland from being clogged by biomass.

While the wetland removed TN at very low efficiency, the removal rate, $14-30 \mathrm{~kg} \mathrm{ha}^{-1} \mathrm{~d}^{-1}$, was much higher than $3 \mathrm{~kg} \mathrm{ha}^{-1} \mathrm{~d}^{-1}$ of TKN loading recommended by Hammer (1992). In removing TN physical mechanisms made major contributions of $80-92 \%$. Those TN organic solids removed by physical mechanisms, except minor portions of $2-4 \%$ lost by stripping, were mostly 
Table 4

Estimated mass removals of key pollutants by various mechanisms

\begin{tabular}{|c|c|c|c|c|}
\hline \multirow[t]{2}{*}{ Item $^{\mathrm{a}}$} & \multirow[t]{2}{*}{ Mechanism } & \multicolumn{3}{|c|}{ Mass removal rate, $\mathrm{kg} \mathrm{ha}^{-1} \mathrm{~d}^{-1}$ (removal contribution, \%) } \\
\hline & & Phase I & Phase II & Phase III \\
\hline \multirow[t]{4}{*}{ SS } & Overall & $300(100)$ & $618(100)$ & $300(100)$ \\
\hline & Physical & $300(100)$ & $618(100)$ & $300(100)$ \\
\hline & Microbial & $0(0)$ & $0(0)$ & $0(0)$ \\
\hline & Plant uptake & $0(0)$ & $0(0)$ & $0(0)$ \\
\hline \multirow[t]{4}{*}{ COD } & Overall & $582(100)$ & $1056(100)$ & $318(100)$ \\
\hline & Physical & $429(74)$ & $740(70)$ & $165(52)$ \\
\hline & Microbial $^{\mathrm{b}}$ & $153(26)$ & $316(30)$ & $153(48)$ \\
\hline & Plant uptake & $0(0)$ & $0(0)$ & $0(0)$ \\
\hline \multirow[t]{8}{*}{$\mathrm{TN}$} & Overall & $30(100)$ & $25.3(100)$ & $14(100)$ \\
\hline & Physical & $27.6(92)$ & $21.5(85)$ & $11.2(80)$ \\
\hline & Stripping $^{\mathrm{c}}$ & $0.5(2)$ & $1.1(4)$ & $0.3(2)$ \\
\hline & Others $^{\mathrm{d}}$ & $27.1(90)$ & $20.4(81)$ & $10.9(78)$ \\
\hline & Microbial & $2.0(7)$ & $3.3(13)$ & $2.3(16)$ \\
\hline & Assimilation ${ }^{\mathrm{e}}$ & $0.6(2)$ & $1.9(8)$ & $0.9(6)$ \\
\hline & Nitri/denitrif & $1.4(5)$ & $1.4(5)$ & $1.4(10)$ \\
\hline & Plant uptake & $0.5(2)$ & $0.5(2)$ & $0.5(4)$ \\
\hline \multirow[t]{4}{*}{$\mathrm{TP}$} & Overall & $11.3(100)$ & $21.8(100)$ & $8.8(100)$ \\
\hline & Physical & $11.1(98.2)$ & $21.2(97.2)$ & $8.5(96.5)$ \\
\hline & Microbialg & $0.2(1.7)$ & $0.5(2.3)$ & $0.2(2.3)$ \\
\hline & Plant uptake & $0.1(0.1)$ & $0.1(0.5)$ & $0.1(1.2)$ \\
\hline
\end{tabular}

${ }^{a}$ The abbreviations are: SS, suspended solids; COD, chemical oxygen demand; TN, total nitrogen; and TP, total phosphorus.

${ }^{\mathrm{b}}$ Estimated from the digestion of volatile suspended solids (VSS), expressed in COD equivalent. Assuming $60 \%$ of suspended solids were VSS, for which the digestion efficiency was $60 \%$, and the COD conversion factor was $1.42 \mathrm{mg}$ COD/mg VSS (Gaudy and Gaudy, 1980).

${ }^{\mathrm{c}}$ Estimation was based on $0.5 \%$ ammonia present in the influent at $\mathrm{pH}=7.0$ (Sawyer et al., 1994).

${ }^{\mathrm{d}}$ Removal mechanisms excluding ammonia stripping, microbial assimilation, nitrification/denitrification, and plant uptake.

${ }^{\mathrm{e}}$ Microbial assimilation was based on $12 \%$ nitrogen content of biomass yielded, where the bacterial yielded coefficient was assumed 0.05 mg VSS/ mg COD (Metcalf and Eddy Inc., 1991).

${ }^{\mathrm{f}}$ Removal by nitrification/denitrification processes, in which nitrification was the limiting step. The oxygen transport rate by water hyacinth was measured around $51.3 \mathrm{~g} \mathrm{O}_{2} \mathrm{~d}^{-1}$, and half of which was proposed for nitrification use (Lee, 1996).

${ }^{\mathrm{g}}$ Phosphorus content was assumed to be $3 \%$ biomass yielded.

retained in the wetland cell. If complete $\mathrm{TN}$ removal is to be carried out, nitrification and denitrification should be prevailing (Stowell et al., 1981). Unfortunately, in this wetland, the nitrification was estimated below 1.4 $\mathrm{kg} \mathrm{ha}^{-1} \mathrm{~d}^{-1}$, due to low oxygen supplied by the plants, although the denitrification could proceed very well, as shown by the very low effluent nitrate $\mathrm{N}, 1.1-1.7 \mathrm{mg}^{-1}$. The low growth rate of water hyacinth also made the TN removed by plant uptake very low, only about 0.5 $\mathrm{kg} \mathrm{ha}^{-1} \mathrm{~d}^{-1}$.

The TP removal was also dominated by physical mechanisms, with significant removal rates of 8.5-21.2 $\mathrm{kg} \mathrm{ha}^{-1} \mathrm{~d}^{-1}$ (Table 4 ). There was only about $1.7-2.3 \%$ of the TP removed by microbial assimilation. And water hyacinth took only $0.1-1.2 \%$ of TP. In physical mechanism, removal of TP was primarily related to the retention capacity of root bed media (Pant et al., 2001) and equilibrium phosphorus concentration. In this wetland the retention capacity of the root bed media was not yet maturated, but anaerobic conditions made equilibrium phosphorus concentration increased substantially (Richardson, 1985; Reedy et al., 1998), thus showing TP removal efficiency could not be enhanced greatly.

\section{Conclusions}

The SSFCW applied in swine wastewater treatment under heavy loads was successfully demonstrated, and operated with three hydraulic retention times. Constituents of $\mathrm{SS}, \mathrm{COD}$, and $\mathrm{BOD}_{5}$, appeared to be effectively removed by the wetland as measured by both mass removal rates and reduction efficiency. Moreover, the wetland system responded well to changing loads from 303 to $624 \mathrm{~kg} \mathrm{ha}^{-1} \mathrm{~d}^{-1}$ for SS and from 390 to $1370 \mathrm{~kg} \mathrm{ha}^{-1}$ for COD. This was attributed to the wetland having high specific surface area and being characterized with anaerobic conditions. In regard to the removals of phosphorus and nitrogen, the wetland exhibited higher removal rates than most other wetlands, although it gave low reduction efficiencies. This quality of treated effluent suggested the SSFCW system be suitable in combination with land application for total management of swine wastewater. Being followed by land application as terminal treatment, the SSFCW system can be fully exploited with heavy loads, thus leading to greatly increase its competitive edge in swine wastewater treatment. 


\section{Acknowledgements}

The authors would like to thank the Environmental Protection Bureau of Pingtung and the Environmental Protection Administration, Taiwan, Republic of China, for financially supporting this research.

\section{References}

APHA, 1989. Standard Methods for the Examination of Water and Wastewater, sixth ed. American Public Health Association, Washington, DC, USA.

Cronk, J.K., 1996. Constructed wetlands to treat wastewater from dairy and swine operations: a review. Agric., Ecosyst. Environ. 58, 97-114.

Dierberg, F.E., DeBusk, T.A., Jackson, S.D., Chimney, M.J., Pietro, K., 2002. Submerged aquatic vegetation-based treatment wetlands for removing phosphorus from agricultural runoff: response to hydraulic and nutrient loading. Water Res. 36, 1409-1422.

Finlayson, M., Chick, A., Oertzen, I., Michell, D., 1987. Treatment of piggery effluent by an aquatic plant filter. Biol. Wastes 19, 179-196.

Gaudy Jr., A.F., Gaudy, E.T., 1980. Microbiology for Environmental Scientist and Engineers. McGraw-Hill, Inc, New York.

Hammer, D.A., Pullin, B.P., McCaskey, T.A., Eason, J., Payne, V.E.W., 1993. Treating livestock wastewaters with constructed wetlands, in: Moshiri, G.A. (Ed.), Constructed Wetlands for Water Quality Management. Lewis Publishers, Ann Arbor, Mich.

Hill, V.R., Sobesy, M.D., 1998. Microbial indicator reductions in alternative treatment systems for swine wastewater. Water Sci. Technol. 38 (12), 119-122.

Humenik, F.J., Szögi, A.A., Hunt, P.G., Broome, S., Rice, M., 1999. Wastewater utilization: a place for managed wetlands-Review. Asian-Australian J. Animal Sci. 12 (4), 629-632.

Hunt, P.G., Poach, M.E., 2001. State of the art for animal wastewater treatment in constructed wetlands. Water Sci. Technol. 44 (11-12), $19-25$.
Kadlec, R.H., Knight, R.L., 1996. Treatment Wetlands. CRC press Inc, USA.

Knight, R.L., Payne Jr., V.W.E., Borer, R.E., Clarke Jr., R.A., Pries, J.H., 2000. Constructed wetlands for livestock wastewater management. Ecol. Engrg. 15, 41-55.

Lee, C.C., 1996. Performance of Constructed Wetland Treating Highly Concentrated Wastewater, M.S. Thesis, National Pingtung University of Science and Technology, Pingtung, Taiwan, ROC (in Chinese).

Metcalf and Eddy Inc., 1991. Wastewater Engineering, Treatment, Disposal, and Reuse. McGraw-Hill Inc., New York.

Neralla, S., Wever, R.W., Lesikar, B.J., Persyn, R., 2000. Improvement of domestic wastewater quality by subsurface flow constructed wetlands. Bioresour. Technol. 75, 19-25.

Pant, H.K., Reddy, K.R., Lemon, E., 2001. Phosphorus retention capacity of root bed media of sub-surface flow constructed wetlands. Ecol. Engrg. 17, 345-355.

Reedy, K.R., Oconnor, G.A., Gale, P.M., 1998. Phosphorus sorption capacity of wetland soils and stream sediments impacted by dairy effluent. J. Environ. Qual. 27, 438-447.

Richardson, C.J., 1985. Mechanisms controlling phosphorus retention capacity in freshwater wetlands. Science 228, 1424-1427.

Sawyer, C.N., McCarty, P.L., Park, G.F., 1994. Chemistry for Environmental Engineering, fourth ed. McGraw-Hill, Inc, New York.

Sievers, D.M., 1997. Performance of four constructed wetlands treating anaerobic swine lagoon effluents. Trans. ASAE 40 (3), 769-775.

Stone, K.C., Hunt, P.G., Humenik, F.J., Johnson, M.H., 1998. Impact of swine waste application on ground and stream water quality in an eastern coastal plain watershed. Trans. ASAE 41 (6), 16651670.

Stowell, R.R.L., Colt, J., Tchobanoglous, G., 1981. Concepts in aquatic treatment system design. J. Environ. Engrg. ASCE 107, 919-940.

Szögi, A.A., Hunt, P.G., Humenik, F.J., 2000. Treatment of swine wastewater using saturated-soil-culture soybean and flooded rice system. Trans. ASAE 43 (2), 327-335. 